\title{
Regeneration and expansion of Quercus tomentella (island oak) groves on Santa Rosa Island
}

\author{
Jay Woolsey ${ }^{1}$, Cause Hanna ${ }^{2} \dagger$, Kathryn McEachern $^{3}$, Sean Anderson ${ }^{1}$, and Brett D. Hartman ${ }^{1, *}$ \\ ${ }^{1}$ Environmental Science and Resource Management Program, CSU Channel Islands, Camarillo, CA \\ ${ }^{2}$ Santa Rosa Island Research Station, CSU Channel Islands, Camarillo, CA \\ ${ }^{3}$ U.S. Geological Survey, Western Ecological Research Center, Channel Islands Field Station, Ventura, CA
}

\begin{abstract}
Quercus tomentella (island oak) is an endemic species that plays a key functional role in Channel Island ecosystems. Growing in groves on highland ridges, Q. tomentella captures fog and increases water inputs, stabilizes soils, and provides habitat for flora and fauna. This cloud forest system has been impacted by a long history of ranching, and restoration efforts are underway that include erosion control, leaf litter capture, fog capture, and reforestation. To inform retoration efforts, we explored tree regeneration and the potential for Q. tomentella grove expansion on Santa Rosa Island. We delineated current and historic groves at Black Mountain by comparing stand maps from 1989 and aerial photographs from 1994 and 2015. We evaluated regeneration in the outlying areas by recording the location, diameter at breast height, number of trunks, height class, percent crown mortality, nurse plant species (if present), and reproductive status for all 4355 outlying seedlings, saplings, and mature trees. We defined outliers as individuals that were $15 \mathrm{~m}$ outside of the canopy of island oak groves. There are 14 groves at Black Mountain, and grove size expanded by an average of 36.9\% (SD 18.5\%) between 1994 and 2015. Nurse plants correlated positively with outlier tree height and reduced percent crown mortality. This effect is potentially due to increased fog drip from nurse plant species such as Quercus pacifica (island scrub oak), Heteromeles arbutifolia (toyon), and Baccharis pilularis (coyote brush). These results indicate that Q. tomentella is regenerating and that nurse plants can serve as catalysts for ecosystem restoration.
\end{abstract}

Resumen.-El Quercus tomentella (encino de la isla) es una especie endémica que desempeña un papel funcional clave en los ecosistemas de las Islas del Canal (Channel Islands). El Q. tomentella, que crece en las arboledas de las cordilleras montañosas, captura la niebla, aumenta el aporte de agua, estabiliza los suelos y proporciona un hábitat para la flora y la fauna. Este sistema de bosque de niebla ha sido afectado por una larga historia de ganadería, por lo que se están llevando a cabo labores de restauración que incluyen control de la erosión, recogimiento de hojarasca, captura de niebla y reforestación. Para proporcionar un informe de las labores de restauración, estudiamos la regeneración de los árboles y el potencial de expansión de los bosques de Q. tomentella en la Isla Santa Rosa. Demarcamos los bosques actuales y los históricos en Black Mountain comparando mapas forestales de 1989 con fotografías aéreas de 1994 y 2015. Evaluamos la regeneración en las áreas periféricas registrando la ubicación, el diámetro a la altura del pecho, el número de troncos, el tipo de altura, el porcentaje de mortalidad de las copas, las especies de plantas nodrizas (si las hubiere) y el estado reproductivo de las 4355 plántulas periféricas, retoños y árboles maduros. Definimos como individuos atípicos a aquellos encinos que se encontraron a $15 \mathrm{~m}$ por arriba del dosel de los robledales de la isla. Existen 14 arboledas en Black Mountain, las cuales se expandieron en un promedio de $36.9 \% \pm 18.5 \%$ entre 1994 y 2015 . Las plantas nodrizas se correlacionaron positivamente con la altura de los árboles atípicos y con un reducido porcentaje de mortalidad de las copas. El efecto de las especies nodrizas podría deberse al aumento del goteo de niebla de especies tales como el Quercus pacifica (roble de matorral insular), la Heteromeles arbutifolia (baya de navidad) y el Baccharis pilularis (arbusto coyote). Estos resultados indican que el Q. tomentella se está regenerando y que las plantas nodrizas pueden servir como catalizadores en la restauración del ecosistema.

Oaks play a key functional role in many global woodland communities, and many oak species are in decline (Costa et al. 2011). One such species is Quercus tomentella (island oak), which grows on highland ridges in the Channel Islands of California (Fig. 1). Quercus tomentella is a narrow endemic species listed as vulnerable by the International Union for the Conservation of Nature (IUCN) and of limited distribution by the California Native Plant Society (CNPS) (IUCN 2015, CNPS 2015). A history of intensive ranching at the

*Corresponding author: brett.hartman@csuci.edu $\dagger$ Deceased 


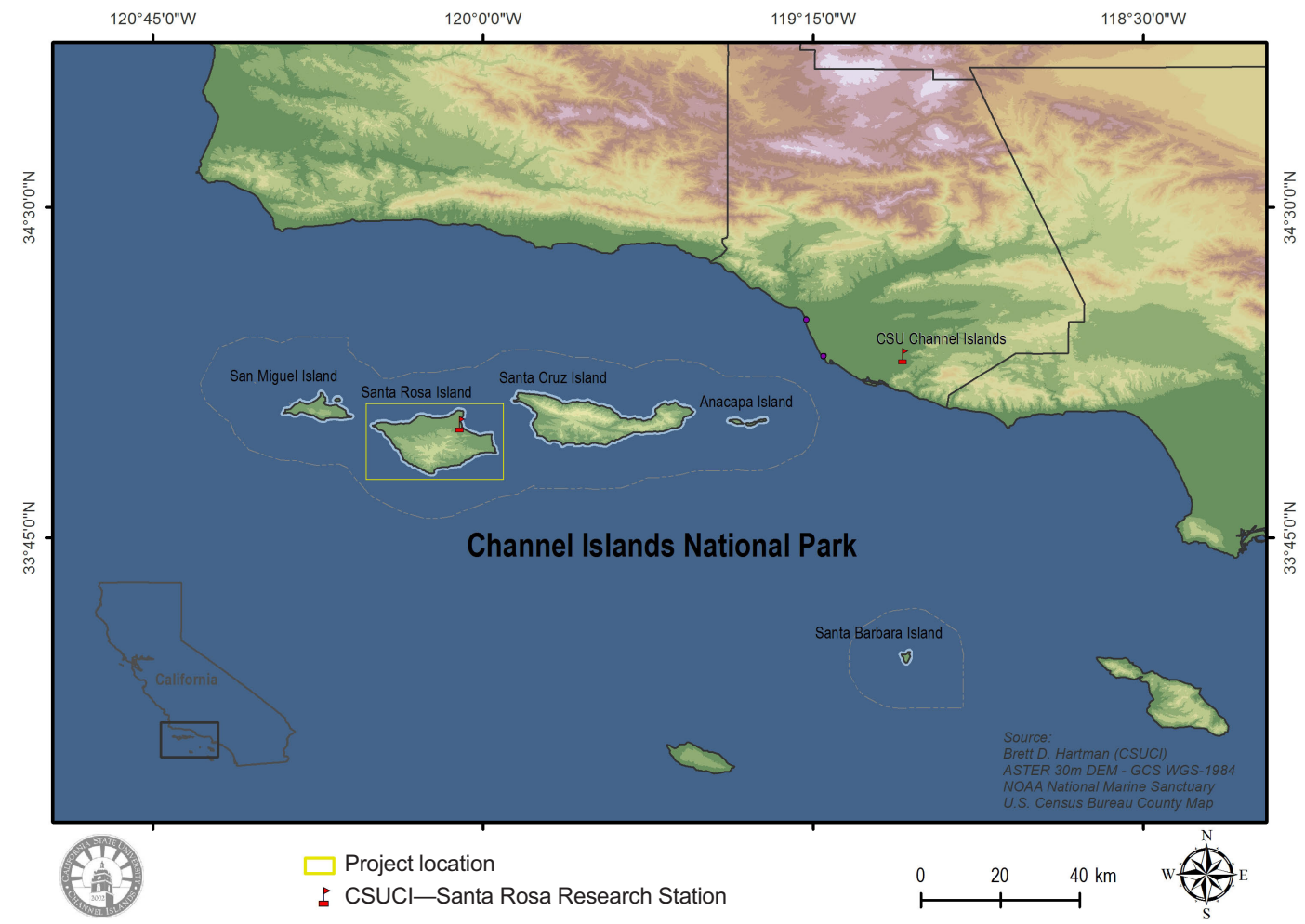

Fig. 1. Project location in Channel Islands National Park, California.

Channel Islands impacted Q. tomentella groves, and their regeneration may now be hindered by reduced fog drip, soil loss, and lack of seedling establishment and survival.

Quercus tomentella captures water from fog to create moist cloud forest conditions below canopy driplines, where the abundant leaf litter (up to $60 \mathrm{~cm}$ deep) promotes infiltration and maintains soil moisture (Fig. 2) (Kindsvater 2006, Williams et al. 2008, Schumann et al. 2014). Fog drip has been observed in pines, oaks, and shrubs across the Channel Islands (Williams et al. 2008, Fischer et al. 2009, Evola and Sandquist 2010, Wang et al. 2017). Fog drip contributes to groundwater recharge to maintain downslope springs and stream base flow (Stock et al. 2003, Sawaske and Freyberg 2015, Rastogi et al. 2016, Wang et al. 2017). Quercus tomentella groves also provide habitat for ecologically important island vertebrate and invertebrate species (Koenig and Stahl 2007, Puerta-Piñero et al. 2010, Sanchez and Hudgens 2015).

There has been a progressive loss of pine and oak woodlands on the highland ridges due to the long history of sheep and cattle ranching at the Channel Islands (Allen 1996). Acorn predation by rooting feral pigs disturbed root systems and impacted oak regeneration (Barrios-Garcia and Ballari 2012). Reduced vegetative cover and disturbance to biological soil crusts also induced widespread gully erosion and landslides in the highlands (Brumbaugh et al. 1982, Renwick 1982, Van Vuren and Coblentz 1987, Klinger et al. 2002, Pinter and Vestal 2005, Perroy et al. 2012). Many ridgelines were denuded down to the exposed bedrock or regolith (Fig. 2).

Like other California oaks, the regeneration success of $Q$. tomentella following disturbance is unclear (Smith 1993, McCreary 2001). The potential mechanisms of island oak regeneration are via cloning and seed dispersal by gravity, birds, and mammals. Clones develop from root sprouts emerging through the soil and leaf litter to expand the canopy extent as trees reach maturity (Liñán et al. 2011). Acorns fall off trees, roll downhill and then germinate (Matsuda et al. 1989). Birds may also contribute to dispersion by foraging in the 

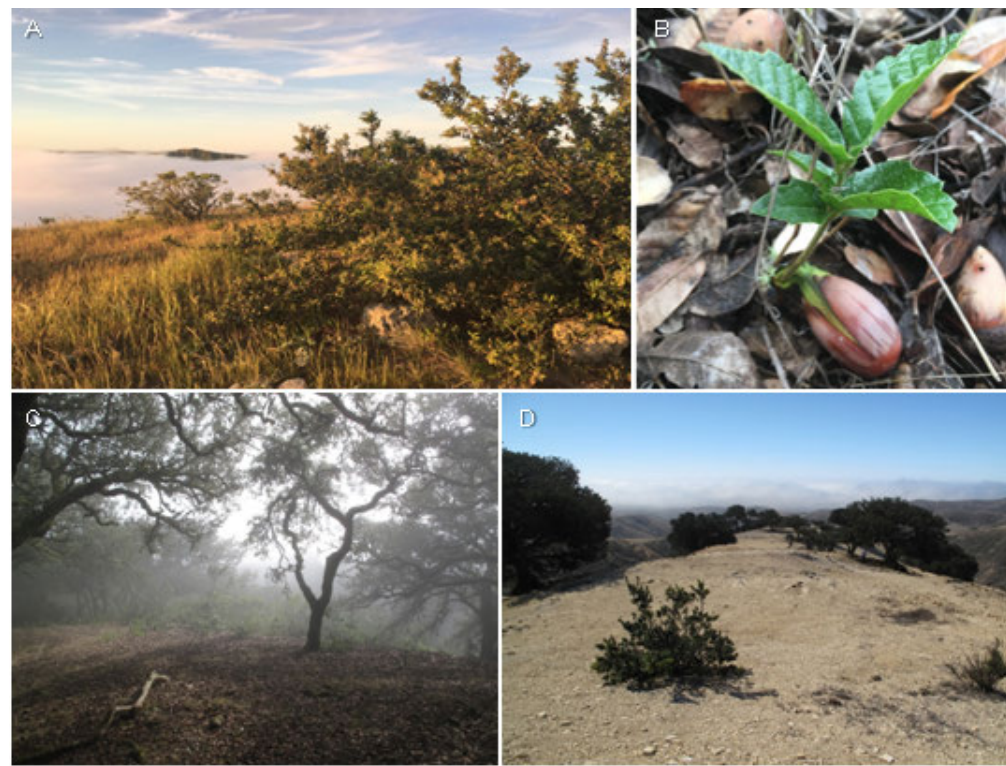

Fig. 2. Representative photos of Quercus tomentella on Santa Rosa Island: A, fog bank in the lower reaches of the watershed below Black Mountain; B, acorn germination in leaf litter; C, fog drip occurring in a grove at Black Mountain; D, bare and denuded ridgeline on Soledad Peak where temperature, moisture, and nutrient levels are adverse to germinating seedlings. The few surviving $Q$. tomentella trees on Soledad Peak have exposed roots, indicating extensive topsoil loss.

groves and relocating acorns to nests, caches, or other germination locations. However, unlike on Santa Cruz Island, there are no Aphelocoma insularis (Island Scrub Jay) individuals to disperse island oak seeds through lost caches on Santa Rosa Island (SRI) (Atwood 1980, Kindsvater 2006, Pesendorfer et al. 2014, Morán-López et al. 2015). Seedeating rodents that forage in island oak groves may also cache acorns in burrows, which can lead to germination and stand growth $(\mathrm{Li}$ and Zhang 2003, Puerta-Piñero et al. 2010). Rodent dispersion is confined to the endemic island deer mouse (Peromyscus maniculatus santarosae), which is the only rodent on SRI.

Following establishment of Channel Islands National Park in 1980, ecosystem restoration efforts were initiated to address resource degradation. The first phase was passive restoration following the removal of all nonnative ungulates, and the resulting changes were dramatic. Woody vegetation types increased and grassland and bare ground cover decreased over time (Klinger et al. 2002, Corry and McEachern 2009, Beltran et al. 2014, Rick et al. 2014, Summers et al. 2018). The current active restoration phase consists of erosion control, leaf litter capture, and fog capture to build soil resources and prepare for island oak and bishop pine (Pinus muricata) reforestation in the highlands (Kindsvater 2006, Klemm et al. 2012).

There is a need to better understand $Q$. tomentella regeneration to improve restoration efforts at the Channel Islands. In this study, we present preliminary results of an ongoing study of $Q$. tomentella regeneration at Santa Rosa Island (SRI). The study was conducted at 14 groves at Black Mountain. We evaluated changes in grove size over time and mapped tree regeneration in the outlying areas. We also investigated the effect of nurse plants such as Heteromeles arbutifolia (toyon), Baccharis pilularis (coyote brush), Adenostoma fasciculatum var. prostratum (prostrate chamise), and Arctostaphylos confertiflora (Santa Rosa Island manzanita) on island oak stem diameter, height, and health. Nurse plants may increase regeneration health and vigor due to increased soil moisture from fog drip.

\section{Study AREA}

Santa Rosa Island is the second largest island $\left(215.3 \mathrm{~km}^{2}\right)$ in Channel Islands National Park and is located $42 \mathrm{~km}$ off the coast of 
California (Fig. 1). The rugged terrain is dominated by east-west trending ridgelines with deep canyons, with the highest peak at $482.5 \mathrm{~m}$ above sea level. The island has a maritime Mediterranean climate, precipitation mostly occurs between October and April, and summer fog drip contributes significant moisture to ecosystems. Strong prevailing northwest winds can deplete soil moisture and cause wind erosion on denuded ridgelines. Vegetation comprises valley and foothill grassland, riparian areas, coastal scrub (coyote brush scrub, coastal sage scrub, lupine scrub, caliche scrub, and coastal bluff scrub), island chaparral, and woodlands (oak, mixed, and island pine woodlands) (Clark et al. 1990). Among the tree species found on the island, 4 are rare and ecologically important: $Q$. tomentella, Pinus torreyana ssp. insularis (Santa Rosa Island Torrey pine), P. muricata, and Lyonothamnus floribundus ssp. aspleniifolius (island ironwood). Quercus tomentella is located predominantly in 2 areas of SRI, on Black Mountain and the Soledad Ridge.

Land use on SRI dates back 13,000 years to the Island Chumash. Ranching was introduced in 1843, with herd sizes of approximately 100,000 sheep and 5000 cattle by the early 1900s (Livingston 2006). Channel Islands National Park was created in 1980, and Santa Rosa was purchased and incorporated into the park in 1986. Animal removal began shortly thereafter. All feral pigs were eradicated by 1992, cattle were removed in 1998, and deer and elk were systematically culled and removed by the end of 2011 (McEachern et al. 2016). Based on analysis of Landsat TM5 and ETM + satellite imagery from 1989 to 2015, scrub cover increased by $41 \%$, island chaparral increased by $14 \%$, and woodland cover increased by $109 \%$. In contrast, valley and foothill grassland cover decreased by $31 \%$ and bare ground by $68 \%$ (Summers et al. 2018). Despite evidence of recovery following nonnative grazer removal, approximately $5.6 \mathrm{~km}^{2}$ of the island remains bare and may require more active intervention.

The study site is located off Soledad Road on Black Mountain, approximately $6.4 \mathrm{~km}$ west of Bechers Bay pier and the CSUCI Santa Rosa Island Research Station. The site starts $0.44 \mathrm{~km}$ east of the weather station at the first Q. tomentella on the hillside adjacent to Soledad Road, and extends $1.04 \mathrm{~km}$ west to the last Q. tomentella on this hillside. The study area is a predominantly north-facing slope.

\section{Methods}

We used a combination of field and geospatial methods to evaluate current and historic Q. tomentella grove size and map the current distribution of outlier trees on Black Mountain. We set up a perimeter for each of the current groves by taking a GPS waypoint at the stem of every adult $Q$. tomentella located at the edge of the groves. We defined a grove as a semicontinuous canopy cover with $<15$-m gaps between adult island oak driplines. Adult and juvenile trees with $\geq 15$-m gaps from the main grove were considered outlier trees. The waypoints identifying the trees at the edge of each grove allowed us to identify the edge of island oak groves and differentiate Q. tomentella from Q. pacifica and H. arbutifolia in both current and historic aerial photographs. We delineated all groves and their canopy lines at Black Mountain by interpreting aerial photos from 4 January 2015 in Google Earth ${ }^{\mathrm{TM}}$, using the GPS waypoints at the grove edges to guide the polygon delineation.

The objective of the study was to compare the current (2015) Q. tomentella groves and outlier trees on Black Mountain with a historic grove map digitized from a 1:250,000 topographic map created in 1989 (Kindsvater 2006). In addition to investigating the 1989 map, we delineated the historic Q. tomentella groves by interpreting aerial photos from 2 September 1994 in Google Earth ${ }^{\mathrm{TM}}$. We used the 1989 grove polygons and GPS waypoints established at the adult trees at edges of the Q. tomentalla groves to guide the historic grove delineation. The mature trees were assumed to still be alive and present in the 1994 aerial photos. Using this process, we generated polygons suitable for comparison to the 2015 grove delineations.

All grove polygons were imported to a GIS environment and projected in North American Datum 1983, Universal Transverse Mercator Zone 11N (NAD 83, UTM Zone $11 \mathrm{~N}$ ), the same projection as used for the GPS waypoints of the outlier trees. We calculated grove size in hectares for 1994 and 2015 and calculated the total change and the percent change over time. We determined whether grove size has changed significantly between 
TABLE 1. Height classifications for Quercus tomentella outlier trees.

\begin{tabular}{lcc}
\hline $\begin{array}{l}\text { Height } \\
\text { classification }\end{array}$ & $\begin{array}{c}\text { Height } \\
\text { range }(\mathrm{cm})\end{array}$ & $\begin{array}{c}\text { Height } \\
\text { median }(\mathrm{cm})\end{array}$ \\
\hline 1 & $<30$ & 15 \\
2 & $30-160$ & 95 \\
3 & $161-300$ & 230 \\
4 & $301-600$ & 450 \\
5 & $>600$ & 700 \\
\hline
\end{tabular}

1994 and 2015 by using a paired sample Student's $t$ test.

We searched the exterior of the groves for outlying seedlings, saplings, and adult trees (outlier trees) and collected a waypoint at each outlier tree. We defined seedlings as stems $\leq 0.1 \mathrm{~cm} \mathrm{DBH}$ (diameter at breast height), saplings as stems between 0.2 and $5 \mathrm{~cm} \mathrm{DBH}$, and adults as stems $>5 \mathrm{~cm}$ DBH. Note that we were not able to differentiate between stems established by seed germination from stems established as root suckers (clones) without digging to observe root systems. For each stem we recorded DBH, number of trunks, height class (Table 1), percent crown mortality (5\% intervals), nurse plant species (if present), and reproductive status (yes/no). Reproductive status was determined by a visual scan for acorns growing on the tree. We defined a nurse plant as a tree or shrub that had a dripline that overlapped with a $Q$. tomentella seedling or the trunk, roots, or canopy of a sapling and therefore could provide water via fog drip. Adult outlier Q. tomentella trees were also considered nurse plants if oak seedlings or saplings were growing beneath them. For steep slopes where it was unsafe to collect data, we calculated the coordinates of outlier trees by measuring cardinal direction and distance from a Rangefinder ${ }^{\mathrm{TM}}$ placed at a known location. Binoculars were used to estimate DBH, number of trunks, and height class of outliers on steep and inaccessible slopes. We also made natural history observations about dispersal and patterns of tree regeneration.

We tested the correlations between nurse plant species and outlier tree DBH, height class, and percent crown mortality with a Browne-Forsythe ANOVA assuming unequal variance and a Games-Howell post hoc comparison of means, a robust test for nonnormally distributed data. We excluded $15.3 \%$ of the outlier trees from this analysis, as we excluded outlier trees that were estimated with a Rangefinder ${ }^{\mathrm{TM}}$ and outlier trees that were also considered adult nurse trees.

\section{RESUlTs}

There are 14 island oak groves at Black Mountain, and these ranged from 0.1 to 1.6 ha in size in 2015. All groves expanded $36.9 \%$ (SD 18.5\%) on average $(P=0.029)$ from 1994 to 2015 (Fig. 3). The smallest grove expansion was $8.1 \%$ and the largest grove expansion was $78.5 \%$.

We mapped 4355 Q. tomentella outlier trees on Black Mountain (Fig. 4). The majority of outlier trees are seedlings or saplings, with adult outlier trees making up only $12.2 \%$ (Fig. 5). The majority of the adult trees were visible in both the 1994 and 2015 aerial photos. While the majority of outlier trees are clustered around existing groves, outlier seedlings and saplings are widely distributed. Many were found $>200 \mathrm{~m}$ from existing groves or adult trees and/or dispersed across geographic barriers such as ravines and ridgelines. A total of $39.3 \%$ of the outlier trees had nurse plants (Table 2). The most common nurse plants were Q. tomentella $(37.0 \%)$ and B. pilularis (30.8\%), with Q. pacifica (15.5\%), A. fasciculatum (11.3\%), A. confertifolia (2.4\%), and $H$. arbutifolia (1.8\%) less commonly observed as nurse plants.

There was a statistically significant increase in outlier tree height if a $Q$. tomentella, $B$. pilularis, Q. pacifica, or $H$. arbutifolia nurse plant was present, compared to outlier trees with no nurse plant (Table 2). However, there was no difference in outlier tree height if an A. fasciculatum or A. confertifolium nurse plant was present. There was also a statistically significant decrease in percent crown mortality if a Q. tomentella or $H$. arbutifolia nurse plant was present, compared to outlier trees with no nurse plant (Table 2). However, there was no difference in percent crown mortality if a B. pilularis, Q. pacifica, A. fasciculatum, or C. confertifolia nurse plant was present. There was no difference between the DBH of outlier trees with nurse plants and outlier trees with no nurse plants (Table 2).

We found 3 Peromyscus maniculatus (deer mouse) acorn caches; however, only the exterior of the acorns were present and the seeds were not viable. The P. maniculatus caches were located in sandy caverns, indicating that the 


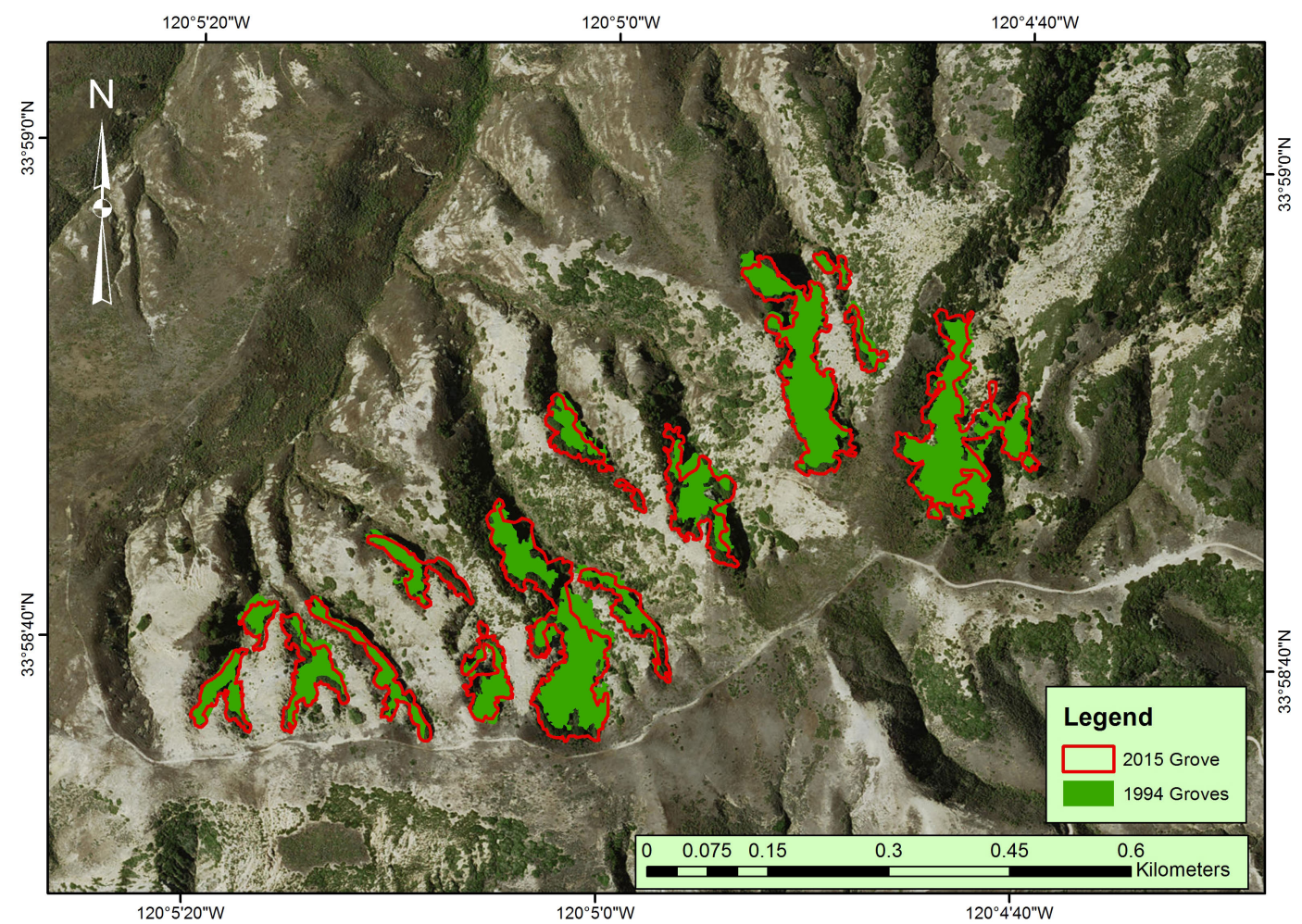

Fig. 3. Comparison of the 1994 and 2015 Quercus tomentella groves at Black Mountain, Santa Rosa Island.

acorns were eaten in a safe location rather than stashed for future use. We found 2 sites with dead branches stuffed with acorns, providing evidence of Melanerpes formicivorus (Acorn Woodpecker) activity on Black Mountain. However, none of these acorns were viable. Pipilo maculatus (Spotted Towhee) individuals were seen kicking acorns downhill while foraging, and no Corvus corax (Common Raven) individuals were sighted with acorns.

\section{Discussion}

Quercus tomentella groves have exapnded from 1994 to 2015. Downslope expansion and infill from regeneration or cloning appears to be occurring across all groves. This contrasts with many oak species (e.g., Q. douglasii [blue oak], Q. lobata [valley oak], and $Q$. suber [cork oak]) in Mediterranean climates, where regeneration is sparse and patchy and species are in overall decline (Smith 1993, McCreary 2001, Pausas et al. 2009). Given the spatial distribution of the 4355 outlier trees, it is likely that Q. tomentella groves at Black Mountain will continue to expand as seedlings mature and form additional canopy. The abundance of seedlings and saplings compared to adult trees indicates that regeneration and grove expansion may be a recent phenomenon following nonnative grazer removal. The extent and spatial distribution of grove expansion will be influenced by tree survival over time.

Despite the abundance of outlier trees, there are very few seedlings and saplings inside the groves except under canopy gaps where sunlight can reach the forest floor. In 2003-2004, Kindsvater (2006) sampled 14 plots ranging from 208 to $220 \mathrm{~m}^{2}$ within Q. tomentella stands and found that 6 of the 14 stands had seedlings (plants $<2.5 \mathrm{~cm}$ in stem diameter) ranging in number from 1 to 27 , while saplings (plants 2.5 to $8 \mathrm{~cm}$ in stem diameter) were not present in any plot. Kindsvater attributed this size-class pattern to decreased herbivory associated with the removal of feral animals from the island that allowed some seedlings to survive in recent years.

Nurse plants positively affected the growth of $Q$. tomentella regeneration, increasing tree 


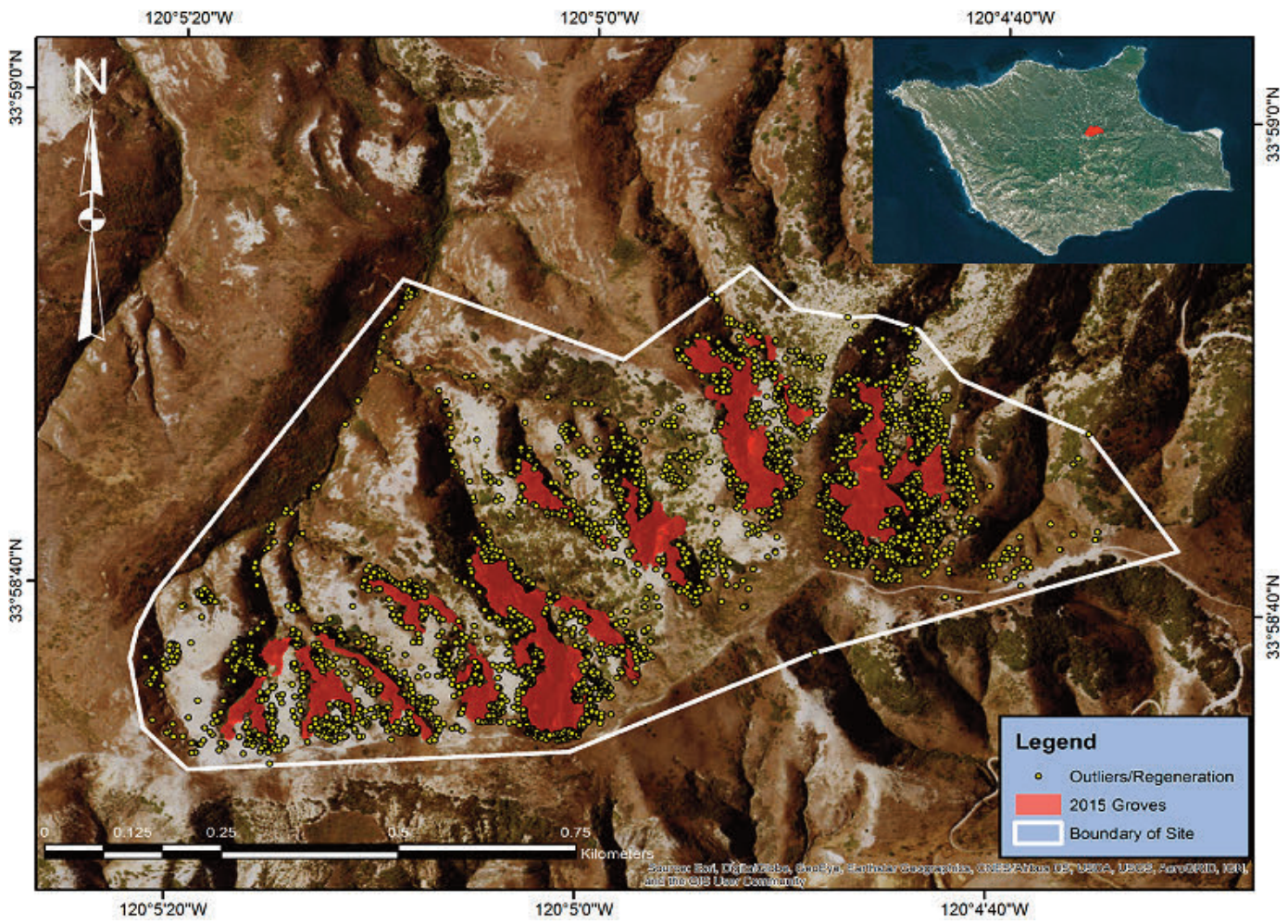

Fig. 4. The locations of the 4355 Quercus tomentella outlier seedlings, saplings, and adult trees in comparison to 14 groves mapped in 2015 at Black Mountain, Santa Rosa Island. Based on field observation and terrain analysis, regeneration is mostly occurring downslope of the existing canopy edges.

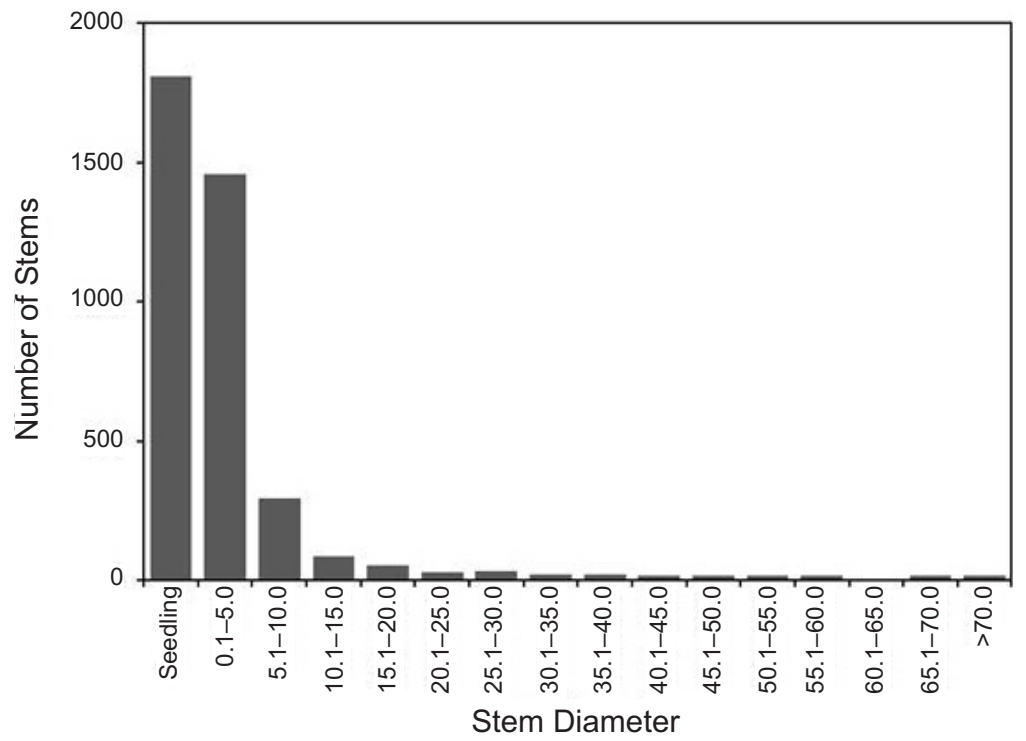

Fig. 5. Stem size class distribution of the outlier trees at Black Mountain, Santa Rosa Island. 
TABLE 2. The effect of nurse plant species on diameter at breast height (DBH), height, and crown mortality of Quercus tomentella outlier trees. Means are given with standard error in parentheses. Statistical significance was tested with a Browne-Forsythe ANOVA assuming unequal variance and a Games-Howell post hoc comparison of means.

\begin{tabular}{lcccc}
\hline Nurse plant & $N$ & DBH $(\mathrm{cm})$ & Height $(\mathrm{cm})$ & $\%$ Mortality \\
\hline Quercus tomentella & 536 & $2.9(0.2)$ & $240.3(6.6)^{*}$ & $8.8(0.5)^{*}$ \\
Baccharis pilularis & 446 & $3.1(0.2)$ & $270.1(6.1)^{*}$ & $10.2(0.7)$ \\
Quercus pacifica & 224 & $2.8(0.3)$ & $251.2(8.5)^{*}$ & $9.8(0.8)$ \\
Adenostoma fasciculatum var. prostratum & 163 & $2.0(0.5)$ & $190.5(10.8)$ & $11.0(1.2)$ \\
Arctostaphylos confertifolia & 34 & $1.9(0.4)$ & $226.9(22.9)$ & $9.6(5.5)$ \\
Heteromeles arbutifolia & 25 & $4.7(1.1)$ & $317.1(21.1)^{*}$ & $7.0(1.0)^{*}$ \\
No nurse plant & 2241 & $2.6(0.1)$ & $211.0(3.3)$ & $12.0(0.3)$ \\
\hline
\end{tabular}

*The mean difference is significant $(P<0.01)$ based on a Browne-Forsythe ANOVA assuming unequal variance. Statistical significance was calculated based on a comparison of outlier trees with nurse plants and outlier trees with no nurse plant using a Games-Howell post hoc comparison of means.

height and decreasing crown mortality. The most effective nurse species are Q. tomentella and H. arbutifolia, followed by B. pilularis and Q. pacifica. The positive effect of nurse plants may be due to a combination of fog drip and the leaf litter that accumulates below nurse plants (Kindsvater 2006, Fischer et al. 2009, Evola and Sandquist 2010, Schumann et al. 2014). This combination creates not only a favorable germination substrate, but also enough soil moisture and nutrients for growth and survival over the long term. The presence of a nurse plant also indicates that suitable soils are already present at that location, an important consideration given the elevated levels of historic erosion on the highland ridges of SRI.

Although the larger and taller canopies of Q. tomentella or $H$. arbutifolia are more effective at fog capture, we suggest that $B$. pilularis is an important species to manage for ecosystem restoration. Baccharis pilularis is a winddispersed species that is well adapted to growing in disturbed environments, and it can also contribute moisture from fog drip. Baccharis pilularis was observed growing on the outskirts of the island oak groves, and is a relatively easy species to establish and maintain over the long term. Establishing such disturbance-adapted shrubs as nurse species may be important in areas impacted by erosion to build the soil resources necessary for the establishment of Q. tomentella and other large woody species such as $H$. arbutifolia and Q. pacifica.

Adenostoma fasciculatum and Arctostaphylos confertifolia are not effective as nurse species. This may be due to the low mat-growing growth form of A. fasciculatum that does not promote abundant fog drip and the unfavorable rocky convex slopes that both A. fasciculatum and
A. confertifolia more commonly grow on. However, these species may contribute to other aspects of ecosystem restoration.

This study indicates that Q. tomentella regeneration and grove expansion is occurring at Black Mountain. Kindsvater (2006) developed a spatial model projecting potential core habitat for Q. tomentella from her mapped distribution of occupancy and seedling/sapling distributions. She estimated that $7 \%$ to $8 \%$ of SRI had characteristics of elevation, slope, and aspect that matched sites where Q. tomentella was growing and recruiting. In 2004, recruitment was occurring in about $1 \%$ of those projected areas. Our results generally match the pattern of core habitat predicted by the model in the Black Mountain area.

More research is needed to understand Q. tomentella cloning, dispersal, and seedling establishment. The pattern of outlier seedling and sapling distribution indicates that abundant tree regeneration occurs beyond the areas proximate to adult trees where root suckers typically appear. However, it is not known what proportion of the outlier trees have resulted from sexual versus asexual reproduction. We observed few instances of bird and mammal dispersion, but it is possible that caches are present but not observed in the field. Future research will focus on field observations of bird and mammal behavior to better elucidate patterns of acorn dispersal. Differentiating between gravity dispersion and cloning is difficult without digging up roots. Future research will also focus on understanding the relationship between $Q$. tomentella regeneration and terrain (slope steepness, curvature, aspect, elevation), fog capture, and leaf litter accumulation. Identifying the optimal landforms for island oak regeneration can increase restoration effectiveness. Increasing 
the study area to include other parts of SRI and other islands would also increase our understanding of $Q$. tomentella regeneration.

This study provides a baseline of the $Q$. tomentella distribution and regeneration on Black Mountain that can be monitored into the future. Increased understanding of tree distribution, dispersal, and regeneration of this species is vital to developing effective ecosystem restoration management and can guide the allocation and prioritization of National Park Service restoration efforts.

\section{ACKNOWLEDGments}

We thank Keith Westcott and The Havasi Wilderness Foundation for funding this research and the CSUCI Santa Rosa Island Research Station for logistical and technical support. Special thanks go to Dr. Don Rodriguez, Dr. Mario Pesendorfer, Dr. Scott Sillett, Ryan Summers, Tess Silvestri, and the ESRM 428 Intermediate GIS and ESRM 499 Capstone classes. Without these funders, advisors, and students, this project could not have happened. Any use of trade, product, or firm names in this publication is for descriptive purposes only and does not imply endorsement by the U.S. Government.

\section{Literature Cited}

ALLEN, K. 1996. Island of the cowboys: Santa Rosa Island. Santa Cruz Island Foundation, Santa Barbara, CA.

ATwood, J. 1980. Social interactions in the Santa Cruz Island Scrub Jay. Condor 82:440-448.

Barrios-Garcia, M.N., and S. Ballari. 2012. Impact of wild boar (Sus scrofa) in its introduced and native range: a review. Biological Invasions 14:2283-2300.

Beltran, R.S., N. Kreidler, D.H. Van Vuren, S.A. MorRison, E.S. Zavaleta, K. Newton, B.R. Tershy, and D.A. CRoll. 2014. Passive recovery of vegetation after herbivore eradication on Santa Cruz Island, California. Restoration Ecology 22:790-797.

Brumbaugh, R.W., W.H. Renwick, and L.L. Loeher. 1982. Effects of vegetation change on shallow landsliding: Santa Cruz Island, California. USDA 58: 397-402.

[CNPS] California Native Plant Society. 2015. Island oak, Quercus tomentella. [Accessed December 2015]. http://calscape.org/quercus-tomentella-(island-oak) ?srchcr $=$ sc560d $98863 \mathrm{ec} 8 \mathrm{~b}$.

Clark, R.A., W.L. Halvorson, A.A. Sawdo, and K.C. Danielson. 1990. Plant communities of Santa Rosa Island, Channel Islands National Park. Technical Report No. 42. Cooperative National Park Resources Study Unit, University of California-Davis, Davis, CA.

Corry, P.M., and A.K. McEachern. 2009. Patterns in post-grazing vegetation changes among species and environments, San Miguel and Santa Barbara
Islands. Pages 201-214 in C.C. Damiani and D.K. Garcelon, editors, Proceedings of the 7th California Islands Symposium. Institute for Wildlife Studies, Arcata, CA.

Costa, A., M. Madeira, J. Santos, and Â. Oliveira. 2011. Change and dynamics in Mediterranean evergreen oak woodlands landscapes of Southwestern Iberian Peninsula. Landscape and Urban Planning 102:164-176.

Evola, S., and D.R. SAndquist. 2010. Quantification of fog input and use by Quercus pacifica on Santa Catalina Island. In: Oak ecosystem restoration on Santa Catalina Island, California: proceedings of an on-island workshop, February 2-4, 2007. Catalina Island Conservancy, Avalon, CA.

Fischer, D.T., C.J. Still, ANd A.P. Williams. 2009. Significance of summer fog and overcast for drought stress and ecological functioning of coastal California endemic plant species. Journal of Biogeography 36:783-799.

[IUCN] InTERnational Union for CONSERVATION OF NAtURE. 2015. The IUCN Red List of Threatened Species: Quercus tomentella. [Accessed December 2015]. http://www.iucnredlist.org/details/30959/0

KindsvateR, L.C. 2006. Conservation and restoration of the endemic island oak, Quercus tomentella in Channel Islands National Park using a habitat approach. Doctoral dissertation, University of California, Davis, CA. ProQuest Dissertations Publishing 61:1013-1021.

Klemm, O., R.S. Schemenauer, A. Lummerich, P. CereCeda, V. Marzol, D. Corell, J. van Heerden, D. Reinhard, T. GHerezGhiHer, J. Olivier, Et AL. 2012. Fog as a fresh-water resource: overview and perspectives. AMBIO 41:221-234.

Klinger, R.C., P. Schuyler, and J.D. Sterner. 2002. The response of herbaceous vegetation and endemic plant species to the removal of feral sheep from Santa Cruz Island, California. Pages 141-154 in C.R. Veitch and M.N. Clout, editors, Turning the tide: the eradication of invasive species. Proceedings of the International Conference on Eradication of Island Invasives. Occasional Paper of the IUCN Species Survival Commission No. 27.

Koenig, W., and J. Stahl. 2007. Late summer and fall nesting in the Acorn Woodpecker and other North American terrestrial birds. Condor 109:334-350.

Li, H., AND Z. Zhang. 2003. Effect of rodents on acorn dispersal and survival of the Liaodong oak (Quercus liaotungensis Koidz.). Forest Ecology and Management 176:387-396.

Liñán, J., M. Cantos, J. Troncoso, J. García, A. FernánDEZ, AND A. Troncoso. 2011. Some propagation methods for cloning holm oak (Quercus ilex L.) plants. Open Life Sciences 6:359-364.

Livingston, D.S. 2006. Historic resource study: a history of the islands within Channel Islands National Park. Technical Report to Channel Islands National Park, Ventura, CA. 917 pp.

Matsuda, K., AND J.R. MCbRide. 1989. Germination characteristics of selected California oak species. American Midland Naturalist 122:66-76.

MCCREARY, D.D. 2001. Regenerating rangeland oaks in California. UC ANR Publications 21601. 62 pp.

McEachern, K., T. Atwater, P.W. Collins, K. Faulkner, AND D.V. Richards. 2016. Managed island ecosystems. Pages 755-778 [Chapter 34] in H. Mooney and 
E. Zavaleta, editors, Ecosystems of California. University of California Press, Berkeley, CA.

Morán-López, T., C. Alonso, and M. Díaz, 2015. Landscape effects on jay foraging behavior decrease acorn dispersal services in dehesas. Acta Oecologica 69:52-64.

Pausas J.G., T. Marañón, M. Caldeira, and J. Pons. 2009. Natural regeneration. Island Press 10:115-124.

Perroy, R.L., B. Bookhagen, O.A. Chadwick, and J.T. HowarTh. 2012. Holocene and anthropocene landscape change: arroyo formation on Santa Cruz Island, California. Annals of the Association of American Geographers 102:1229-1250.

Pesendorfer, M., K. Langin, B. Cohen, Z. Principe, S. Morrison, AND T.S. SilletT. 2014. Stand structure and acorn production of the island scrub oak (Quercus pacifica). Monographs of the Western North American Naturalist 7:246-259.

Pinter, N., AND W.D. Vestal. 2005. El Niño-driven landsliding and postgrazing vegetative recovery, Santa Cruz Island, California. Journal of Geophysical Research: Earth Surface 110:1-17.

Puerta-Piñero, C., J. María Gómez, and E. Schupp. 2010. Spatial patterns of acorn dispersal by rodents: do acorn crop size and ungulate presence matter? Oikos 119:179-187.

Rastogi, B., P.A.Williams, D.T. Fischer, S.F. Jacobellis, K. McEachern, L. Carvalho, C. Jones, S.A. BAGUSKas, AND C.J. STILl. 2016. Spatial and temporal patterns of cloud cover and fog inundation in coastal California: ecological implications. Earth Interactions 20:1-19.

Renwick, W. 1982. Landslide morphology and processes on Santa Cruz Island, California. Geografiska Annaler. Series 64:149-159.

Rick, T.C., T.S. Sillett, C.K. Ghalambor, C.A. Hofman, K. Ralls, R.S. Anderson, C.L. Boser, T.J. Braje, D.R. Cayan, R.T. Chesser, Et AL. 2014. Ecological change on California's Channel Islands from the Pleistocene to the Anthropocene. BioScience 64: 680-692.

Sanchez, J., And B. Hudgens. 2015. Interactions between density, home range behaviors, and contact rates in the Channel Island fox (Urocyon littoralis). Ecology and Evolution 5:2466-2477.

SaWaske, S.R., and D.L. Freyberg. 2015. Fog, fog drip, and streamflow in the Santa Cruz Mountains of the California Coast Range. Ecohydrology 8:695-713.

Schumann, R.R., S. Minor, D. Muhs, and J. Pigati. 2014. Landscapes of Santa Rosa Island, Channel Islands National Park, California. Monographs of the Western North American Naturalist 7:48-67.

Smith, D.W. 1993. Oak regeneration: the scope of the problem. Pages 40-52 in D.L. Loftis and C.E. McGee, editors, Oak regeneration: serious problems, practical recommendations. General Technical Report SE-84, USDA Forest Service, Southeastern Forest Experiment Station.

Stock, J., J. Coil, And P.V. Kirch. 2003. Paleohydrology of arid southeastern Maui, Hawaiian Islands, and its implications for prehistoric human settlement. Quaternary Research 59:12-24.

Summers, R., J. Masukawa, and B.D. Hartman. 2018. The influence of slope on vegetation recovery following nonnative grazer removal on Santa Rosa Island, California. Western North American Naturalist 78:787-798.

Van Vuren, D., And B.E. Coblentz. 1987. Some ecological effects of feral sheep on Santa Cruz Island, California, USA. Biological Conservation 41:253-268.

Wang, L., K.F. KaseKe, AND M.K. Seely. 2017. Effects of non-rainfall water inputs on ecosystem functions. Wiley Interdisciplinary Reviews: Water 4:1-18.

Williams, A., C. Still, D. Fischer, and S. Leavitt. 2008. The influence of summertime fog and overcast clouds on the growth of a coastal Californian pine: a treering study. Oecologia 156:601-611.

Received 1 March 2017

Revised 16 January 2018

Accepted 14 March 2018

Published online 17 December 2018 